\title{
Barcode DNA Edelweis (Anaphalis javanica) Berdasarkan Gen matK
}

\author{
Muzakir Rahalus a, Maureen Kumaunang a* Audy Wuntu a, Julius Pontoh a \\ aJurusan Kimia, FMIPA, Unsrat, Manado
}

\begin{tabular}{l} 
K A T A K UNC I \\
\hline edelweis \\
matK \\
barcode DNA \\
analisis kekerabatan
\end{tabular}

\begin{abstract}
A B S T R A K
DNA barcode merupakan metode identifikasi organisme hidup dengan menggunakan urutan DNA pendek ( \pm 500 pasang basa). Tujuan dari penelitian ini adalah memperoleh barcode DNA Edelweis dan menganalisis kemiripan gen matK Edelweis (Anaphalis javanica) dengan kerabat terdekatnya. Isolasi DNA total Edelweis berhasil dilakukan dengan menggunakan manual prosedur dari InnuPrep Plant DNA Kit yang dimodifikasi. Gen matK parsial telah diisolasi dengan metode Polymerase Chain Reaction (PCR) menggunakan Primer forward matK-1RKIM-f dan Primer Reverse matK-3FKIM-r. Hasil analisis sekuens menghasilkan barcode DNA edelweis berukuran 843 bp. Hasil analisis kemiripan menunjukkan tingkat kekerabatan terdekat dengan $A$. margaritaceae yaitu $99.86 \%$ pada BOLD System dan $100 \%$ pada NCBI.
\end{abstract}

\section{K E Y W O R D S}

edelweiss

matK

DNA barcode

sequence similarity

\section{A B S T R A C T}

DNA barcode is a method to identify living organism by using several short sequences of DNA ( \pm 500 base pairs). The purpose of this study was to obtain a DNA barcode and analyze the similarity of matK genes of edelweis (Anaphalis javanica) with its closest relatives. Isolation of total DNA of edelweis has been succesfully done by using modified manual procedures of InnuPrep Plant Kit. matK partial gene has been isolated by the method of Polymerase Chain Reaction (PCR) using forward primer MATK-1RKIM-f and reverse primer MATK-3FKIM-r. Analysis of DNA sequences of edelweis confirmed its DNA barcode size was $843 \mathrm{bp}$. Furthermore, A. javanica showed similarity $99.86 \%$ in BOLD system and $100 \%$ in NCBI with $A$. margaritaceae.

TERSEDIA ONLINE

29 juli 2015

\section{Pendahuluan}

Anaphalis javanica, yang dikenal secara populer sebagai Edelweis jawa (Javanese edelweiss) atau Bunga Senduro, adalah tumbuhan endemik zona alpina/montana di berbagai pegunungan tinggi Nusantara (Whitten et al, 1992). Dalam keadaan kering bunganya tahan lama dan menimbulkan bau yang khas. Tumbuhan ini hidup pada ketinggian antara 1.600-3.600 $\mathrm{m}$ dari permukaan laut dan dapat hidup pada tanah yang miskin kandungan hara (Aliadi, et al., 1990). Di Sulawesi Utara edelweis terdapat pada kawasan konservasi Cagar

Alam (CA) Gunung Tangkoko, CA Duasudara dan di Gunung Soputan.

Ekstrak edelweis telah digunakan sejak zaman dahulu untuk menyembuhkan penyakit disentri, diare dan TBC. Ekstrak edelweis juga sering ditambahkan ke dalam secangkir susu panas yang dicampur dengan madu. Selain itu, ekstrak edelweis juga bermanfaat sebagai anti penuaan karena mengandung antioksidan dan antimikroba (Whitten et al, 1992).

Di Gunung Soputan sendiri banyak pendaki yang sering mengambil edelweis tanpa memikirkan kelestariannya. Bila pengambilan bunga terus

\footnotetext{
*Corresponding author: Jurusan Kimia FMIPA UNSRAT, Jl. Kampus Unsrat, Manado, Indonesia 95115; Email address: maureen273@yahoo.com Published by FMIPA UNSRAT (2015)
} 
dibiarkan, bukan mustahil suatu saat edelweis akan punah karena tidak dapat berkembang biak dan akibatnya berbagai manfaat kimiawi untuk kesehatan tidak akan ada lagi.

Walaupun saat ini kandungan kimia edelweis telah diketahui banyak manfaatnya dalam bidang kesehatan, tapi penelitian bahan aktif dalam tanaman tersebut belum banyak dilakukan. Hal ini dimungkinkan karena proses pengambilannya yang sulit. Sebagai langkah awal agar dapat menumbuhkan, mengembangkan, dan merekayasa secara genetik edelweis sebagai tanaman kesehatan produktif, maka diperlukan teknik molekuler. Berbagai teknik analisis dalam pemuliaan tanaman yang berdasarkan pada hibridisasi molekuler seperti pada Polymerase Chain Reaction (PCR) membutuhkan DNA dalam jumlah yang cukup dan kualitas yang baik. Oleh karena kandungan senyawa sekunder dalam sel tanaman berbeda-beda maka setiap tanaman membutuhkan prosedur isolasi yang optimum agar diperoleh DNA genom yang dapat digunakan sebagai bahan dalam analisis molekuler (Stoeckle et al., 2011). Salah satu aplikasi analisis molekuler adalah dalam penentuan spesies mahluk hidup.

Metode identifikasi spesies mahluk hidup telah berkembang dari identifikasi morfologi, sampai pada identifikasi molekuler berdasarkan potongan DNA pendek yang disebut"barcode DNA" (Hebert et al., 2003). Barcode DNA memiliki fungsi-fungsi yang aplikatif, di antaranya adalah konfirmasi sampelsampel tanaman obat (Xue dan Li, 2011). Untuk mempelajari keanekaragaman genetik spesies tumbuhan berdasarkan teknik "barcode DNA" adalah dengan menggunakan sekuens DNA dari gen ribulosa-1,5-bifosfat karboksilase ( $r b c \mathrm{~L}$ ) dan gen maturase $\mathrm{K}$ (matK) yang terdapat dalam kloroplas sebagai gen standar (Kress et al., 2005).

Berdasarkan studi literatur, barcode DNA untuk edelweiss (A. javanica) belum pernah dipublikasikan. Oleh karena itu, perlu dilakukan identifikasi DNA barcode edelweis (A. javanica), serta analisis hubungan kekerabatannya dengan tanaman lain.

\section{2. bahan dan Metode}

\subsection{Material}

Alat-alat yang digunakan dalam penelitian ini adalah gelas kimia, timbangan, hotplate, alat elektroforesis, mikropipet, termoblok, Freezer, UV transilluminator, spektrofotometer UV-Vis, dan alat PCR (Biometra T-personal, Jerman).

Bahan-bahan yang digunakan, adalah daun edelweis yang diambil dari Gunung Soputan, InnUPREP Plant DNA kit (Analytik Jena), master mix untuk PCR (GoTaq ${ }^{\circledR}$ Green Master Mix, Promega), primer forward matK-1RKIM-f (5'-ACC CAG TCC ATC TGG AAA TCT TGG TTC -3') dan primer reverse matK3FKIM-r (5'-CGT ACA GTA CTT TTG TGT TAC GAG-3') (Integrated DNA Technology (IDT), Singapura), agarosa (Merck), akuades, etidium bromida (Merck) dan buffer Tris-borat-EDTA (TBE, Promega).

\subsection{Metode}

\subsubsection{Isolasi DNA}

Isolasi DNA total edelweis dilakukan berdasarkan prosedur manual InnuPrep Plant DNA Kit yang dimodifikasi. Sampel edelweis yang telah digerus dimasukkan ke dalam tabung Eppendorf dan ditambahkan Lysis Solution SLS (300 $\mu \mathrm{L})$ dan Proteinase $\mathrm{K}(25 \mu \mathrm{L})$ dan diinversikan beberapa kali sehingga homogen dan diinkubasi pada suhu $55^{\circ} \mathrm{C}$ selama 45 menit menggunakan termoblok, kemudian tabung diinversi beberapa kali setiap 10 menit Prefilter dimasukkan ke dalam tabung penampung kemudian sampel dituangkan ke dalam prefilter dan disentrifugasi $12.000 \mathrm{rpm}$ selama 1 menit. Selanjutnya ditambahkan Binding solution SBS $200 \mu \mathrm{L}$ ke dalam tabung yang berisi supernatant/filtrat. Setelah itu Spin Filter dimasukkan ke dalam tabung penampung kemudian sampel dituangkan ke dalam Spin Filter dan disentrifugasi $12.000 \mathrm{rpm}$ selama 1 menit. Selanjutnya filtrat dibuang dan Spin Filter dimasukkan kembali ke tabung penampung dan ditambahkan Washing Solution HS $500 \mu \mathrm{L}$ dan disentrifugasi $12.000 \mathrm{rpm}$ selama 1 menit. Filtrat dibuang dan dimasukkan kembali Spin Filter ke tabung penampung dan ditambahkan Washing Solution MS $750 \mu \mathrm{L}$ dan disentrifugasi $12.000 \mathrm{rpm}$ selama 1 menit. Filtrat dibuang dan dimasukkan kembali Spin Filter ke tabung penampang dan disentrifugasi $12.000 \mathrm{rpm}$ selama 1 menit. Spin Filter dipindahkan ke tabung Eppendorf, dan ditambahkan larutan pengelusi $100 \mu \mathrm{L}$ dan didiamkan pada suhu ruang selama 1 menit kemudian disentrifugasi $10.000 \mathrm{rpm}$ selama 1 menit. Larutan DNA disimpan dalam freezer $\left(-20^{\circ} \mathrm{C}\right)$.

\subsubsection{Amplifikasi matK Edelweis menggunakan Polymerase Chain Reaction (PCR)}

PCR master mix dibuat dengan menggunakan GoTaq ${ }^{\circledR}$ Green Master Mix (Promega). Reaksi PCR dilakukan dalam volume total $40 \mu \mathrm{L}$. Komposisi reaksi PCR terdiri dari: $2 \mu \mathrm{L}$ DNA templat sampel edelweis, $20 \mu \mathrm{L}$ master mix, $15 \mu \mathrm{L}$ akuades steril, 1,5 $\mu \mathrm{L}$ primer forward matK-3F (5'-CGT ACA GTA CTT TTG TGT TACGAG-3'), dan 1,5 $\mu \mathrm{L}$ primer reverse matK-1R (5'-ACC CAG TCC ATC TGG AAA TCT TGG TTC-3'). Pengaturan suhu mesin PCR untuk denaturasi awal yaitu $95^{\circ} \mathrm{C}$ selama 2 menit. Siklus amplifikasi dilakukan sebanyak 35 kali, yaitu denaturasi dilakukan pada suhu $95{ }^{\circ} \mathrm{C}$ selama 30 detik, penempelan primer dilakukan pada suhu 52 ${ }^{\circ} \mathrm{C}$ selama 1 menit, dan reaksi polimerase dilakukan pada suhu $72{ }^{\circ} \mathrm{C}$ selama 90 detik. Tahap pemantapan dilakukan pada suhu $72{ }^{\circ} \mathrm{C}$ selama 10 menit. Hasil PCR kemudian dielektroforesis dan ditentukan urutan nukleotidanya. Hasil PCR dikirim ke Malaysia (First Base Pte.) untuk dilakukan proses pengurutan nukleotida (sekuensing). 


\subsubsection{Elektroforesis agarosa}

Elektroforesis dilakukan untuk melihat keberhasilan proses PCR. Sebanyak $1 \mathrm{~g}$ agarosa dilarutkan dengan aquades sampai $100 \mathrm{~mL}$ dan dipanaskan dengan hot plate. Beaker glass diangkat saat larutan mulai mendidih dan dituang ke dalam cetakan dan didinginkan pada suhu kira-kira $50{ }^{\circ} \mathrm{C}$. Selanjutnya ditambahkan etidium bromida 0,5 $\mu \mathrm{g} / \mathrm{mL}$. Gel agarosa diletakkan dalam alat elektroforesis yang telah diisi dengan larutan buffer Tris-borat-EDTA 1X. Sampel hasil PCR dimasukkan ke dalam sumur gel elektroforesis. Sebagai standar, digunakan DNAladder $1 \mathrm{~kb}$. Elektroforesis dilakukan pada tegangan $100 \mathrm{~V}$ selama 30 menit. Hasil elektroforesis divisualisasikan menggunakan UVTransiluminator pada panjang gelombang $\lambda=312$ $\mathrm{nm}$ dan didokumentasikan.

\subsubsection{Analisis hasil}

Kromatogram DNA hasil sekuensing disunting menggunakan software Geneious v5.6 (Drummond et. al., 2012). Bagian awal dan akhir hasil kromatogram DNA tersebut dihapus kira-kira 30 bp dan untuk pembacaan nukleotida yang keliru diperbaiki berdasarkan tingkat keakuratan yang terbaca. Hasil sekuensing yang menggunakan primer reverse dilakukan proses reverse and complement kemudian dipadukan dengan hasil sekuensing primer forward mengguanakan Multiple Sequence Comparison by Log-Expectation (MUSCLE) (Edgar, 2004).

Keakuratan amplifikasi gen target diuji dengan memprediksi urutan asam amino berdasarkan sekuens matK. Hal ini dilakukan dengan tujuan untuk melihat adanya kodon stop (UAA, UAG atau UGA) di tengah sekuens gen-gen aktif tersebut sehingga diketahui pasti bahwa yang teramplifikasi bukan gen semu (pseudo gen). Potongan gen matk diidentifikasi lewat Barcode of Life Database (BOLD) system (www.boldsystems.org) (Ratnasingham and Hebert, 2007). Selanjutnya dilakukan analisis kekerabatan edelweis (A. javanica) menggunakan program BLASTn pada National Center for Biotechnology Information (NCBI) (http://ncbi.nlm. nih.gov).

\section{Hasil dan Pembahasan}

\subsection{Isolasi DNA dan Amplifikasi matK Edelweis}

Isolasi DNA total edelweis dilakukan untuk memperoleh templat DNA dalam proses amplifikasi gen matK edelweis. Proses PCR telah berhasil mengamplifikasi matK edelweis yang ditunjukkan melalui hasil elektroforesis seperti dalam Gambar 1. Hasil elektroforesis menunjukkan adanya pita DNA yang jelas dan tebal sebagai bukti keberhasilan amplifikasi matK. Hasil PCR ini selanjutnya disekuensing untuk mengetahui urutan nukleotida matK edelweis.

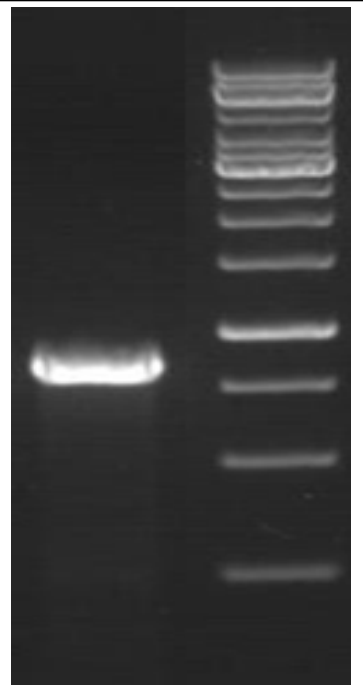

Gambar 1. Elektroforegram pita DNA hasil elektroforesis (S: sampel, M: marker DNA ladder)

\subsection{Analisis Urutan Nukleotida matK dan Penentuan Barcode DNA Edelweis}

Panjang hasil sekuensing (pengurutan) DNA edelweis ( $A$. javanica) dari matK forward adalah 868 $\mathrm{bp}$, sedangkan matK reverse setelah pembalikan 867 bp. Penjajaran antara matK forward dan matk reverse $901 \mathrm{bp}$. Hasil sekuens yang telah dipotong \pm 30 bp pada awal dan akhir untai DNA, menghasilkan sekuens baru (Gambar 2).

Pengujian terhadap asam amino pengkode dari sekuens DNA kloroplas ini menunjukkan tidak adanya kodon stop di tengah-tengah sekuens. Hal ini membuktikan bahwa hasil amplifikasi DNA yang dilakukan sudah valid mengingat gen tersebut pembacaannya dalam bingkai terbuka (open reading frame) enzim-enzim fotosintesis. Pembacaan gen matk menggunakan frame 3 yaitu pembacaan dimulai dari asam amino yang ketiga.

\subsection{Analisis Hubungan Kekerabatan Edelweis}

Penelusuran pada BOLD System untuk sekuens matk dari $A$. javanica menunjukkan belum adanya publikasi mengenai DNA barcode $A$. javanica. Berdasarkan hasil penelusuran BOLD System, terdapat 99 jenis urutan nukleotida yang mempunyai kemiripan dengan $A$. javanica yang terurut dari rank pertama (1) sampai rank ke (99) sesuai panjang sekuens pasangan basa. Hasil penelusuran juga tidak ditemukan kemiripan sampai 100\% (identik). Keseluruhan 99 nukleotida matK berbagai organisme yang berhasil dideteksi melalui BOLD System memilki variasi tingkat kemiripan. Beberapa organisme memiliki tingkat kemiripan yang tinggi, yaitu > $99 \%$ walaupun dari genus yang berbeda, namun masih berada dalam satu famili Asteraceae. Spesies yang kemiripannya sangat tinggi dan masih satu genus dengan $A$. javanica yaitu $A$. margaritaceae dengan tingkat kemiripan 99,88\% dengan panjang sekuens 817 bp (dapat dilihat di rank ke 11 pada Gambar 3, yang 
diberi kotak). Hasil identifikasi pada BOLD system tidak ditampilkan semua. Data yang ditampilkan hanya rank 1-20.

Hasil penelusuran melalui BOLD system diperkuat juga melalui situs NCBI (National Center for Biotechnology Information, http://ncbi.nlm. nih.gov). Dalam situs ini, urutan nukleotida matk $A$. javanica juga tidak ditemukan, yang menunjukkan bahwa penentuan urutan nukleotida matk $A$. javanica belum pernah dilakukan, sehingga penelitian ini merupakan penelitian yang pertama kali dilakukan.



Gambar 2. Sekuens barcode DNA matK dan Asam Amino A. javanica

\begin{tabular}{|c|c|c|c|c|c|c|c|c|}
\hline $\begin{array}{l}\text { Match } \\
\text { Rank }\end{array}$ & Phylum & Class & Order & Family & Genus & Species & Score & Similarityl \\
\hline 1 & Magnoliophyta & Magnoliopsida & Asterales & Asteraceae & Cnaphalium & luteo-album & 835 & 99.53 \\
\hline 2 & Magnoliophyta & Magnoliopsida & Asterales & Asteraceae & Helichrysum & kraussii & 833 & 99.52 \\
\hline 3 & Magnoliophyta & Magnoliopsida & Asterales & Asteraceae & Pseudognaphalium & luteoalbum & 833 & 99.52 \\
\hline 4 & Magnoliophyta & Magnoliopsida & Asterales & Asteraceae & Helichrysum & & 831 & 99.41 \\
\hline 5 & Magnoliophyta & Magnoliopsida & Asterales & Asteraceae & Gnaphalium & sylvaticum & 823 & 98.81 \\
\hline 6 & Magnoliophyta & Magnoliopsida & Asterales & Asteraceae & Pseudognaphalium & luteoalbum & 819 & 99.28 \\
\hline 7 & Magnoliophyta & Magnoliopsida & Asterales & Asteraceae & Helichrysum & petiolare & 818 & 99.4 \\
\hline 8 & Magnoliophyta & Magnoliopsida & Asterales & Asteraceae & Filago & minima & 817 & 98.46 \\
\hline 9 & Magnoliophyta & Magnoliopsida & Asterales & Asteraceae & Filago & minima & 817 & 98.46 \\
\hline 10 & Magnoliophrta & Magnoliopsida & Asterales & Asteraceae & Filage & minima & 817 & 98.46 \\
\hline 11 & Magnoliophyta & Magnoliopsida & Asterales & Asteraceae & Anaphalis & margaritacea & 817 & 99.88 \\
\hline 12 & Magnoliophyta & Magnoliopsida & Asterales & Asteraceae & Pseudognaphalium & oligandrum & 815 & 99.76 \\
\hline 13 & Magnoliophyta & Magnoliopsida & Asterales & Asteraceae & Helichrysum & foetidum & 815 & 99.76 \\
\hline 14 & Magnoliophyta & Magnoliopsida & Asterales & Asteraceae & Antennaria & dioica & 813 & 98.68 \\
\hline 15 & Magnoliophyta & Magnoliopsida & Asterales & Asteraceae & Pterygopappus & lawrencii & 813 & 99.63 \\
\hline 16 & Magnoliophyta & Magnoliopsida & Asterales & Asteraceae & Helichrysum & plicatum & 811 & 99.51 \\
\hline 17 & Magnoliophyta & Magnoliopsida & Asterales & Asteraceae & Helichrysum & pallasii & 811 & 99.51 \\
\hline 18 & Magnoliophyta & Magnoliopsida & Asterales & Asteraceae & Helichrysum & $\begin{array}{l}\text { italicum subsp. } \\
\text { microphyllum }\end{array}$ & 811 & 99.51 \\
\hline 19 & Magnoliophyta & Magnoliopsida & Asterales & Asteraceae & Pseudognaphalium & luteoalbum & 811 & 99.51 \\
\hline 20 & Magnoliophyta & Magnoliopsida & Asterales & Asteraceae & Cnaphalium & norvegicum & 810 & 98.8 \\
\hline
\end{tabular}

Gambar 3. Penelusuran BOLD system untuk sekuens matK Edelweis (A. javanica) 
Berdasarkan hasil analisis BLASTn (Basic Local Alignment Search Tool - nucleotida), ditemukan bahwa matk $A$. javanica memiliki kemiripan terdekat dengan A. margaritaceae sebesar 99\% (Gambar 4, urutan pertama), sehingga memperkuat hasil analisis BOLD System. Kemiripan ini juga diperkuat dengan melihat pohon kekerabatan $A$. javanica yang berada satu root dengan $A$. margaritacea (Gambar 5).

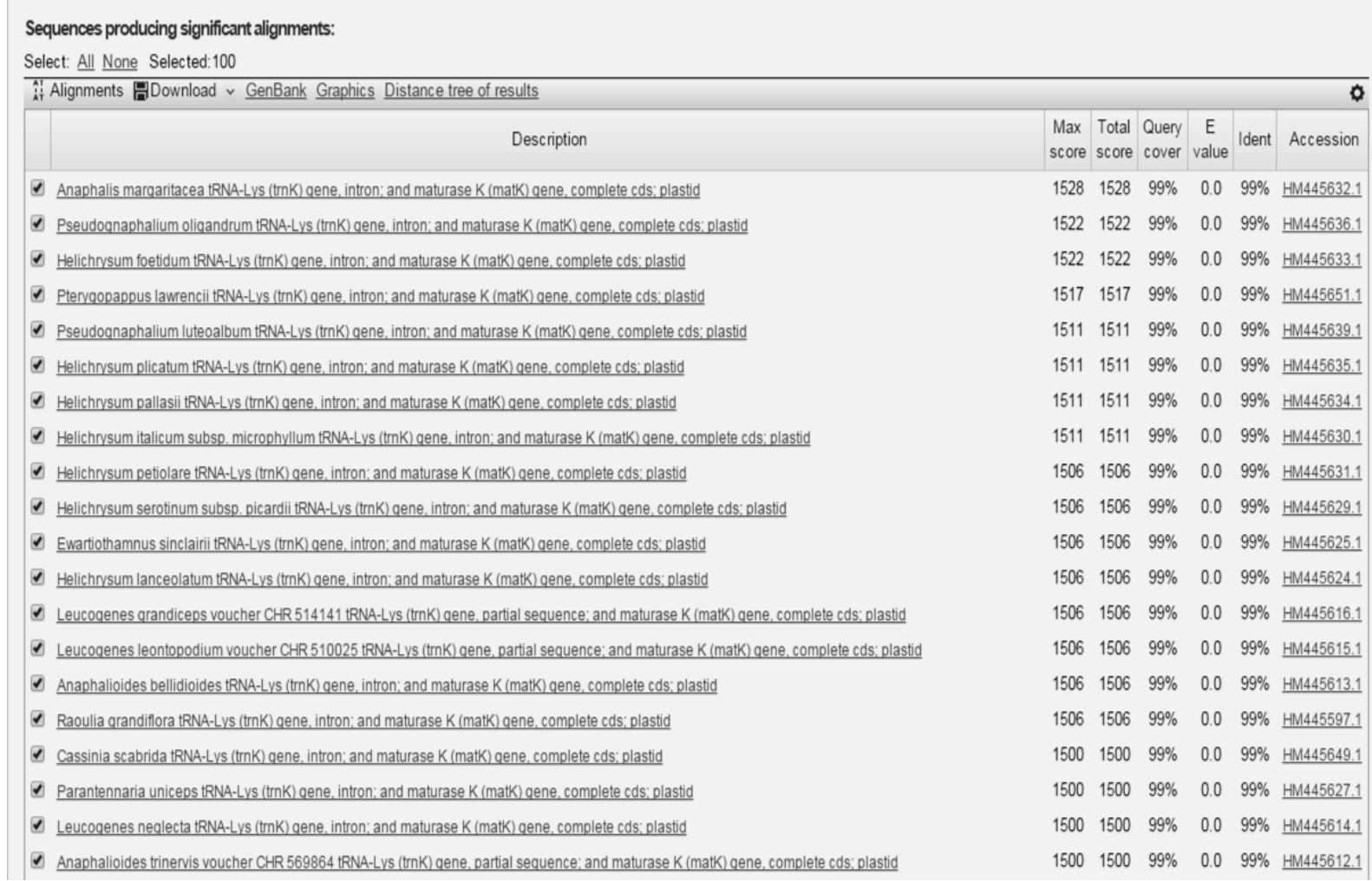

Gambar 4. Hasil analisis BLASTn matK A. javanica

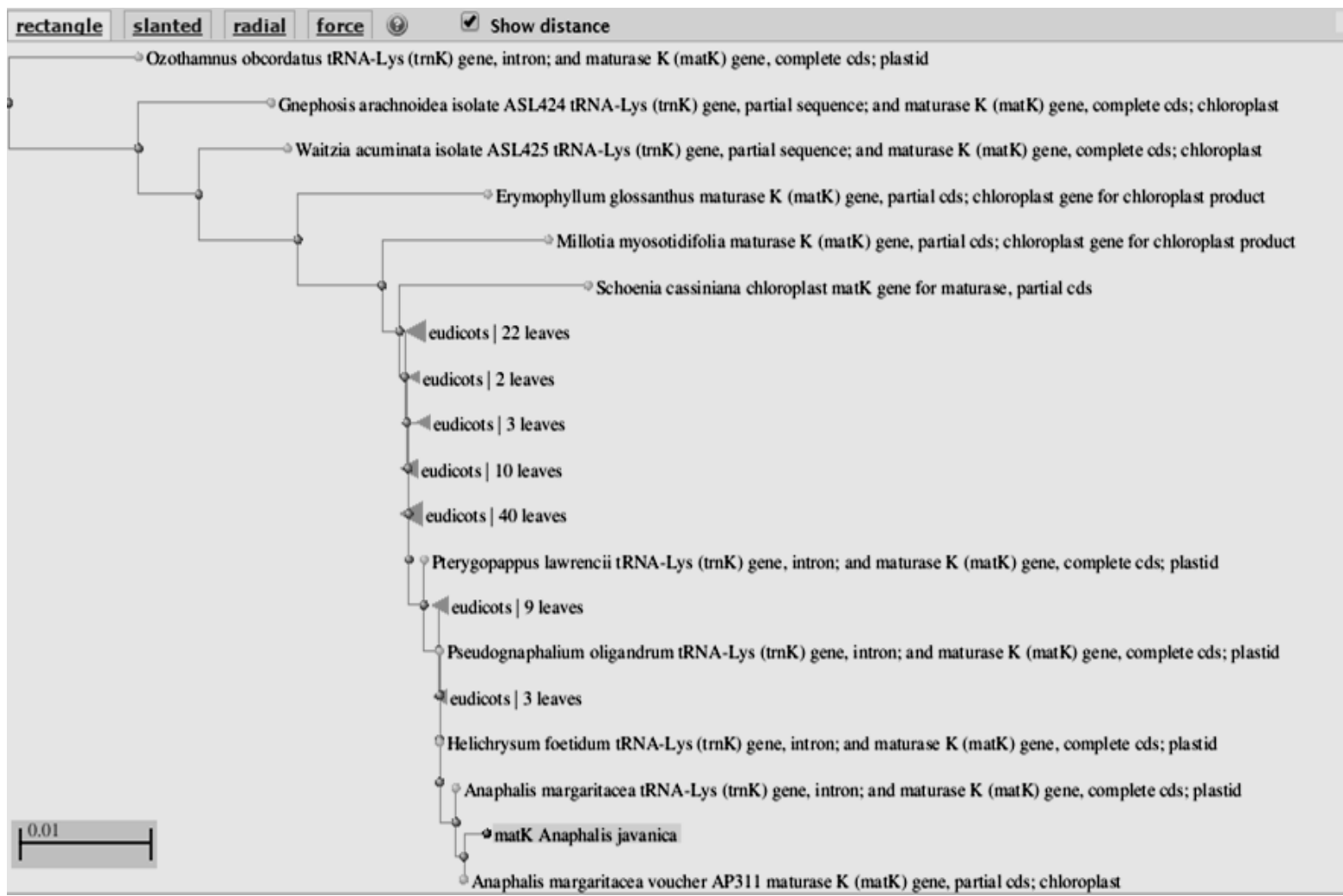

Gambar 5. Pohon kekerabatan A. javanica 


\section{Kesimpulan}

Barcode DNA Edelweis (Anaphalis javanica) telah diperoleh dengan panjang sekuens $843 \mathrm{pb}$ berdasarkan gen matK. Hasil analisis kekerabatan menunjukkan bahwa Edelweis (A. javanica) memiliki kerabat terdekat dengan $A$. margaritacea, dengan tingkat kemiripan $99 \%$.

\section{Daftar Pustaka}

Aliadi, A., A.M.Z. Efrizal,dan Dj. Edje. 1990. Kemungkinan Penangkaran Edelweis (Anaphalis javanica (BI.) Boerl.) dengan Stek Batang (Possibilities of Cultivating Edelweis with Stem Cuttings).Media Konservasi. 3 (1): 37-45.

Drummond, A. J., B. Ashton, S. Buxton, M. Cheung, A. Cooper, M. Kearse, S. Markowitz, S. Sturrock, T. Thierer, and A. Wilson. 2012. Geneious v5.6. Biomatters, New Zeland.

Edgar, R.C. 2004. MUSCLE: Multiple sequence alignment with high accuracy and high throughput. Nucleic Acid Res.5 : 1792-1797.

Hebert, P.D.N., A. Cywinska, S.L. Ball, andJ.R. deWard. 2003. Biological identifications Through DNA Barcodes. Proc Roy Soc Biol Sci. 270: 313321.

Hollingsworth, P.M., S.W. Graham, and D.P. Little. 2011. Choosing and Using a Plant DNA Barcode. PIOS ONE. 6(5): 19254.

Kolondam, B.J., E. Lengkong, dan J. Polii-Mandang. 2012. Barcode DNA Berdasarkan Gen rbcl dan
matK Anggrek Payus Limondok (Phalus tancarvilleae). Jurnal Biologos. 2: 55-62.

Kress, W.J., K. J. Wurdack, E. A. Zimmer, L. A. Weigt,and D.H. Janzen. 2005. Use of DNA Barcodes to Identifity Flowering Plants. PNAS. 102: 8369-8374.

Ratnasingham, S. And P.D.N. Hebert. 2007. BOLD: The Barcode of Life Data System. Molecular Ecology Notes. 7: 355-364.

Stoeckle, M.Y., C.C. Gamble, R. Kirpekar, G. Young, S. Ahmed, and D.P. Little. 2011. Commercial Teas Highlight Plant DNA Barcode Identification Successes and Obstacles. Sci. Rep. 1(42): 1-7.

Van Leeuwen, W. M. D. 1933. Biology of Plants and Animals Occuring in the Higher Part of Mount Pangrango-Gede in West Java. Uitgave van de N. V. Noord Hollandsche. Amsterdam.

Van Steenis, C. G. J. 1978. The Mountain Flora of Java. E. J. B. Leiden.

Wahyudi, D. and R. Azrianingsih. 2011. Distribution and Density of Edelweis (Anaphalis spp) at Mount Batok Bromo Tengger Semeru National Park. Biodiversity Conservation. 1: 25-29.

Whitten, T., Whitten, J., and Cubbit, G. 1992. Wild Indonesia: The Wildlife and Scenery of the Indonesian Archipelago. United Kingdom: New Holland.

Xue, C.Y. \& Li, D.Z. 2011. Use of DNA Barcode Sensulato to Identifity Traditional Tibetan Medicinal Plant Gentianopsis Plasudosa (Gentianaceae). J. Syst Evol.49(3): 267-270. 